\title{
The literature on Triassic, Jurassic and earliest Cretaceous dinoflagellate cysts:
} supplement 2

\author{
James B. Riding* \\ British Geological Survey, Environmental Science Centre, Keyworth, Nottingham NG12 \\ 5GG, United Kingdom \\ *Email: jbri@bgs.ac.uk
}

Since the publication of two literature compilations in 2012 and 2013, 89 further contributions on Triassic, Jurassic and earliest Cretaceous (Berriasian) dinoflagellate cysts have been discovered or were issued recently (i.e. between April 2013 and March 2014). These studies are mostly on the Late Jurassic and Early Cretaceous of Europe. They are all listed herein with digital object identifier (doi) numbers where applicable, and a description of each item as a string of keywords. The 15 most significant publications are briefly summarised.

Keywords: dinoflagellate cysts; Triassic; Jurassic; earliest Cretaceous; literature compilation and synthesis

\section{Introduction}

The literature on Triassic to earliest Cretaceous (Berriasian) dinoflagellate cysts has been comprehensively compiled and reviewed by Riding (2012, 2013). These papers listed 1347 and 94 publications respectively on this topic, with each citation having a string of keywords detailing the scope of the study. During the 12 months since the finalisation of Riding (2013), i.e. as of March 2014, the author has compiled 68 relevant published items which were previously inadvertently overlooked, together with 21 recently-published papers (i.e. issued between April 2013 and March 2014).

These 89 publications are largely on the Late Jurassic and Early Cretaceous of Europe (Table 1), and are listed in Appendix 1 below. Papers on West Europe are most numerous 
(19), and comprise $21.3 \%$ of the overall total (Table 1). This bias towards the Late Jurassic, and the pronounced Euro-centric trend, were also noted by Riding $(2012,2013)$. The nine $(10.1 \%)$ and eight $(9.0 \%)$ contributions from North America and Australasia respectively represent significant advances. Similarly, East Europe and the Middle East were wellrepresented with seven papers (7.9\%) each. Six publications (6.7\%) were on the Arctic, and there were four (4.5\%) each from (North) Africa and South America. China and the Indian subcontinent contributed one paper (1.1\%) each. During 2013-2014, there were apparently no publications from Antarctica, Central America and sub-Arctic Russia. Twenty three papers (25.8\%) were based on material from two or more geographical regions, or with no specific geographical focus (Table 1). Papers specifically on other palynomorph groups such as pollen and spores are not included here.

Partington et al. (1993) is one of the most important publications on the Jurassic biostratigraphy of northwest Europe. These authors defined 33 regionally significant condensed marine successions which contain maximum flooding surfaces for the latest Triassic (Rhaetian) to the earliest Cretaceous (Berriasian/Ryazanian) of the North Sea. These condensed successions have allowed the subdivision of this interval into 32 genetic stratigraphical sequences for the North Sea which were calibrated biostratigraphically using dinoflagellate cysts, foraminifera, ostracoda and radiolaria. In addition to the paper itself, there are two separate, large foldout diagrams (Partington et al. 1993, enclosures 1, 2) inside the back cover of the main volume which document the genetic sequence stratigraphy and the supporting biostratigraphical data. In Riding (2012) these important documents were not mentioned; the complete reference is given herein below.

The contributions of Chen (2013), Riding \& Michoux (2013) and van de Schootbrugge et al. (2013) were listed only with digital object identifier (doi) numbers in Riding (2013) because, at that time, these papers were published online only. The volume and page details for each of these three publications are given in the references below.

\section{Major recent papers}

Fifteen of the 89 publications listed in Appendix 1 are deemed to be especially scientifically significant, and these are briefly reviewed below in two subsections. All dinoflagellate cysts at and below species level mentioned in this section are listed in Appendix 2 with full author citations. 


\subsection{Pre-2013 publications}

Norris (1978) concerns the phylogeny and suprageneric classification of fossil

dinoflagellates. This author erected a new dinoflagellate cyst classification which included three orders, four suborders and 34 families. Following the formal classification, Norris (1978, p. 23-28) gave a perceptive account of the evolutionary and stratigraphical relationships of the dinoflagellate fossil record subdivided into five intervals including the Late Triassic-Early Jurassic, Middle Jurassic and Late Jurassic-Early Cretaceous. The two range charts of the families (Norris 1978, figs. 1,3) are especially interesting. The latter illustrates the significant diversifications during the Early Jurassic, Middle Jurassic and Early Cretaceous. The apparent extinctions of several dinoflagellate cyst families in the Late Cretaceous to Paleogene reflects a sustained decline in diversity during that interval (MacRae et al. 1996, figs. 1-4). An updated dinoflagellate cyst phylogeny was given by Fensome et al. (1993, fig. 192).

Antonescu \& Avram (1980) is a comprehensive account, written in French, of the integrated biostratigraphy of the Lower Cretaceous (Upper Berriasian-Lower Aptian) strata of the Sviniţa area in the Banat region of western Romania. Sviniţa is located on the River Danube, and is within the Pannonian Basin. The material these authors studied is from the Murguceva and Sviniţa formations, and was dated independently using ammonites and calpionellids. Antonescu \& Avram (1980) established four dinoflagellate cyst biozones. These are the Druggidium apicopaucicum and Phoberocysta neocomica biozone (Late Berriasian-Valanginian), the Oligosphaeridium complex and Druggidium deflandrei biozone (Hauterivian), the Dingodinium albertii (now Dingodinium cerviculum) and Meiourogonyaulax stoveri biozone (Early Barremian), and the Prolixosphaeridium parvispinum biozone (Late Barremian-Early Aptian). These units are all concurrent range biozones except the Dingodinium albertii and Meiourogonyaulax stoveri biozone, which is a peak (acme) zone. The Druggidium apicopaucicum and Phoberocysta neocomica biozone was subdivided into two subbiozones. The lower interval is of Late Berriasian-Early Valanginian age, and is characterised by Druggidium apicopaucicum. The upper subbiozone includes prominent Biorbifera johnewingii, Dapsilidinium warrenii and Oligosphaeridium? asterigerum, and is entirely Valanginian in age. The stratigraphical extents of the abundant and relatively diverse dinoflagellate cyst floras were illustrated semiquantitatively in three

101 large range charts, and the assemblages were comprehensively illustrated (Antonescu \& 102 Avram (1980, pls. I-III and IV-XIV respectively). However, these authors did not include 
103 any other diagrams or maps. The overall nature of the associations, and the stratigraphical 104 distributions, of the Lower Cretaceous dinoflagellate cysts from western Romania described 105 by Antonescu \& Avram (1980) are extremely reminiscent of coeval associations from the 106 North Atlantic area between the USA and North Africa (Habib 1975; Habib \& Drugg 1983, 107 1987; Ogg 1994) and southern Europe (Monteil 1992a,b). It seems clear therefore that there 108 was a distinctive western Tethyan dinoflagellate cyst province during the Early Cretaceous 109 which comprised the North Atlantic region east of Mexico and the Gulf of Mexico, eastward 110 into southern Europe. This phytogeoprovince was characterised by taxa such as Amphorula 111 metaelliptica, Biorbifera johnewingii, Dapsilidinium warrenii and Druggidium spp., and is 112 clearly separated from the Boreal and Subboreal provinces. The latter encompass northern

113 Europe and the Arctic which are characterised by distinctly different and more diverse 114 dinoflagellate cyst floras during the Early Cretaceous (see, for example, Heilmann-Clausen 115 1987).

116 The Jurassic marine palynology of the northern part of the Moesian Platform in 117 Romania was studied by Moldovanu (1984), who recognised 15 dinoflagellate cyst 118 associations. These were numbered alphanumerically from J1b (Toarcian) to J3c (Late

119 Tithonian). Moldovanu (1984) used five species of the genus Nannoceratopsis to characterise 120 the Toarcian to Late Bajocian interval. These were Nannoceratopsis triceras (Toarcian121 Aalenian, J1b-J2a), Nannoceratopsis deflandrei (Aalenian, J2a), Nannoceratopsis senex 122 (now Nannoceratopsis deflandrei subsp. senex) (Late Aalenian-Bajocian, J2a-b), 123 Nannoceratopsis gracilis (Early Bajocian, J2b) and Nannoceratopsis spiculata (Late

124 Bajocian, J2c). Carpathodinium predae was used to define the Late Bajocian to Bathonian $125 \mathrm{~J} 2 \mathrm{c}-\mathrm{d}$ assemblage. The Early Bathonian J2d marine palynomorph association was named 126 after Leptodinium subtile. Nannoceratopsis pellucida gives its name to the J2e interval which 127 is of Late Bathonian age. Association J2e-f, of Bathonian-Early Callovian age, was named 128 after Leptodinium regale (now Rynchodiniopsis? regalis). Ctenidodinium ornatum was 129 considered by Moldovanu (1984) to characterise the Callovian (J2f) assemblage. The 130 distinctive species Histiophora ornata is the index taxon for the Late Callovian-Early 131 Oxfordian J2f-J3a assemblage. The Oxfordian dinoflagellate cyst association termed J3a by 132 Moldovanu (1984) was named after Scriniodinium? oxfordianum. This form is, however, 133 likely to be a junior synonym of the distinctive species Scriniodinium crystallinum according 134 to Riding \& Fensome (2002, p. 18). The chorate species Systematophora areolata was used 135 as the nominate taxon for the Kimmeridgian J3b assemblage. The Belodinium dysculum flora $136(\mathrm{~J} 3 \mathrm{~b}-\mathrm{c})$ is of Kimmeridgian-Early Tithonian age. The youngest interval is the Late Tithonian 
137 Cannosphaeropsis mutabilis (J3c) association. "Cannosphaeropsis mutabilis" has never been

138 validly described (Fensome \& Williams 2004, p. 103), thus it is assumed that the J3c

139 association of Moldovanu (1984) should be named after Gochteodinia mutabilis. Moldovanu

140 (1984) also suggested correlations between her biostratigraphical scheme and the work of

141 Beju (1971) on the Bajocian to Kimmeridgian successions of the Carpathian Foreland of

142 Romania.

143 Fensome et al. (1993) is the first and only suprageneric classification scheme for both

144 living and fossil dinoflagellates. Based on the seminal work of Evitt (1985), the principal

145 criteria for this classification are the various tabulation patterns. Prior to Fensome et al.

146 (1993), dinoflagellate cyst classifications such as Sarjeant \& Downie (1966, 1974), Norris

147 (1978) and Dörhöfer \& Davies (1980) were based largely on relatively superficial features

148 such as overall shape, the number and degree of separation of wall layers, and archaeopyle

149 style. The principal breakthrough of this major work was that it represented the first attempt

150 to unify the classification schemes of both thecate dinoflagellates and dinoflagellate cysts.

151 The introductory section (Fensome et al. 1993, p. 1-36) provides an excellent summary of the characteristics of dinoflagellates, with emphasis on tabulation patterns. The major part of this work is the systematic section (Fensome et al. 1993, p. 37-191, in which all the taxonomic subdivisions to the Family level are described. Fensome et al. (1993, p. 205-209) briefly reviewed the phylogeny of dinoflagellates. It is clear that the dinoflagellates are an early protistan group, probably emerging during the Late Precambrian (Taylor 1980). The Middle Triassic to Middle Jurassic appearance and diversification of fossil dinoflagellates was illustrated (Fensome et al., 1993, fig. 192), although this diagram lacks a chronostratigraphical dimension.

Kramers \& Dolby (1993) is an open file report on the Jurassic stratigraphy and palynology of west-central Alberta, western Canada with the principal emphasis on the Jurassic-Cretaceous boundary, which has significant economic importance. The report comprises data and interpretations on core descriptions, palynology and correlations. The detailed results of 268 palynological analyses, undertaken by G. Dolby, were given in Appendix 1 (Kramers \& Dolby 1993, p. 14-115), which comprises the overwhelming majority of this publication.

Antonescu \& Baltreş (1998) largely comprises a lithostratigraphical study of the Nalbant Formation of North Dobrogea in Romania. The Nalbant Formation is dominated by

169 turbidites, comprises seven members and is Norian to Callovian/Oxfordian in age. The

170 Bositra Clays (Bajocian-Bathonian) and the Obretin Formation (Callovian- 
171 Kimmeridgian/?Tithonian) of the Scythien Platform were also considered (Antonescu \&

172 Baltreş 1998, fig. 1). These three units were studied palynologically, and the palynomorph

173 content of key successions was described in running text (Antonescu \& Baltreş 1998, p. 166-

174 175). Selected dinoflagellate cysts and other palynomorphs were extensively illustrated

175 (Antonescu \& Baltreş 1998, pl. I-VII).

176 Feist-Burkhardt $(1999,2012)$ are two biostratigraphy reports commissioned by

177 Nationale Genossenschaft für die Lagerung Radioaktiver Abfälle (NAGRA). This

178 organisation is actively researching potential geological sites to store waste materials and

179 exploring for geothermal heat resources. NAGRA have drilled many exploratory boreholes

180 and naturally have investigated these successions in detail. Feist-Burkhardt $(1999,2012)$

181 represent extremely detailed investigations of several cored boreholes in the Jurassic strata of

182 Germany and Switzerland. Both reports represent assessments of biostratigraphy using both

183 indigenous marine and terrestrially-derived palynomorphs. The abundant and diverse

184 dinoflagellate cyst assemblages allow the high-resolution biostratigraphical subdivision of the

185 boreholes studied. Detailed range charts and colour photographic plates were provided in

186 both reports. Feist-Burkhardt (1999, p. A9-A25) has especially extensive montages of

187 photomicrographs of dinoflagellate cysts.

188 Backhouse \& Balme (2002) is a major study of the Upper Triassic to Lower Jurassic

189 successions in the northern Carnarvon Basin, offshore northwest Australia. These intervals,

190 especially the Upper Triassic strata, host significant gas reserves and hence are extremely

191 economically important. Backhouse \& Balme (2002) studied new material and synthesised

192 legacy data in order to erect a palynomorph zonation for this interval in the Carnarvon Basin,

193 and throughout the Northwest Shelf of Australia. The revised biozonation of Backhouse \&

194 Balme (2002) was integrated into a sequence stratigraphical scheme. Furthermore, the

195 palynomorph spectra were interpreted in terms of their palaeoecological significance. For

196 example, the Hebecysta balmei microplankton zone represents a major marine incursion, and

197 is underlain and overlain by swamp facies. This report was extensively illustrated (Backhouse

198 \& Balme 2002, pls. 1-21).

199 Khowaja-Ateequzzaman et al. (2006) is a major compilation of data on the

200 dinoflagellate cysts from the Mesozoic and Cenozoic successions throughout India. This

201 report alphabetically lists all the genera of fossil dinoflagellates which have been reported

202 from the sedimentary basins of India during the previous 30 years. For each genus the

203 individual species are listed in alphabetic order, together with the ages and locations where

204 they have been reported, with full references to the relevant publications. This was a huge 
compilation exercise and comprises 1643 entries for 225 and 663 dinoflagellate cyst genera and species respectively. Naturally the reference list includes all the publications on Mesozoic and Cenozoic dinoflagellate cysts from the Indian Subcontinent and this, in itself, is an extremely important resource. No range charts or photographic plates were included however.

Birkenmajer \& Gedl (2012) documented the Jurassic and Cretaceous geology and marine palynology of the Maruszyna IG-1 Deep Borehole, which was drilled in the southernmost part of the Pieniny Klippen Belt in south Poland. This important borehole penetrated two large nappe structures. Five of the 29 samples examined were interpreted as being of Jurassic age. The horizons at $1790.2 \mathrm{~m}$ and $1458.5 \mathrm{~m}$ (samples 10 and 9 respectively) were determined to be of Early Bajocian age. Samples 8 and 7, from $1341.8 \mathrm{~m}$ and $1225.5 \mathrm{~m}$ respectively, are Aalenian. This situation with younger material apparently underlying older strata is apparently a function of stratigraphical inversion within the Branisko Nappe. Sample 4 at 846 m was dated as Early Bathonian, and lies within the overlying Pieniny Nappe. The palynofloras were extensively illustrated (Birkenmajer \& Gedl 2012, figs. 5-26).

\subsection{Post-2013 publications}

223 During the year prior to the finalisation of this contribution (i.e. between April 2013 and 224 March 2014), four important papers were published. Gedl (2013) investigated the dinoflagellate cyst biostratigraphy of the Jurassic-Cretaceous Grajcarek Unit from Szczawnica-Zabaniszcze in the Pieniny Klippen Belt, southern Poland. The eight samples examined from the Szlachtowa Formation are dominated by species of Dissiliodinium and Nannoceratopsis, and this unit is interpreted as being Aalenian to Early Bajocian in age (Gedl 2013, figs. 3, 12). The Opaleniec Formation at Szczawnica-Zabaniszcze consistently produced abundant dinoflagellate cysts in the 10 samples studied (Gedl 2013, fig. 10). These include Chytroeisphaeridia chytroeides, Ctenidodinium combazii, Endoscrinium asymmetricum, Meiourogonyaulax caytonensis (as Lithodinia caytonensis) and Nannoceratopsis pellucida. The age of the Opaleniec Formation was interpreted as Late

234 Bathonian, possibly extending to the Early Callovian. The overlying Pieniny Limestone, 235 Kapuśnica and Wronine formations were deduced to be of Early Cretaceous (Late 236 Barremian-Albian) age. succession at Chuangde in Gyangzê County, southern Xizang (Tibet), China was studied by 
Li et al. (2013). Chuangde lies within the Himalayan Tethys, and the palynomorphs are consequently of high thermal maturity due to the high heat flow in this profoundly tectonically active region. The blackened nature of the dinoflagellate cysts and pollen/spores made identification of both somewhat difficult. Based on the palynomorphs, the JurassicCretaceous boundary was identified in the uppermost Weimei Formation. Much of the Weimei Formation yielded abundant poorly-preserved palynomorphs tentatively attributed to the pollen genus Classopollis. However, palynomorph diversity significantly increased in the uppermost Weimei Formation and the lowermost Gyabula Formation (Li et al. 2013, table 1). The dinoflagellate cysts apparently include both characteristically Australasian and European taxa. Furthermore, the presence of characteristically Tethyan forms such as Amphorula sp. and Lanterna sportula is significant.

Mafi et al. (2013) is an investigation of the marine palynomorphs from the Middle to Upper Jurassic Dalichai Formation of northeast Iran. These authors reported non-quantitative data for diverse and well-preserved dinoflagellate cyst associations which were subdivided into four biozones. The units were the Cribroperidinium crispum (Late Bajocian), Dichadogonyaulax sellwoodii (Bathonian-Early Callovian), Ctenidodinium continuum (Callovian) and Ctenidodinium tenellum (Early Oxfordian) biozones. These floras are markedly similar to coeval assemblages reported from northwest Europe (e.g. Riding \& Thomas 1992, Poulsen \& Riding 2003). This indicates that there was no significant dinoflagellate cyst provincialism between northwestern Tethys and greater Europe during the Late Bajocian to Early Oxfordian interval. However, coeval assemblages in northern Europe and the Arctic tend to be significantly higher in diversity than their Tethyan counterparts (Borges et al. 2011, 2012). However, the relative uniformity in Bajocian to Oxfordian dinoflagellate cyst floras between the Middle East and Europe is in stark contrast to the ammonite faunas from northeast Iran, which are distinctly sub-Mediterranean in character. The principal purpose of Williams et al. (2013) was to erect the Niton Member. This lithostratigraphical unit is a distinctive, sandstone-dominated, highly bioturbated member of the Jurassic Fernie Formation of west-central Alberta in western Canada. The Niton Member is regionally mappable, and is Late Oxfordian to Early Kimmeridgian in age based on palynological evidence. Relatively abundant and diverse marine palynofloras allow a subdivision into lower and upper assemblages. These are Late Oxfordian to Early

270 Kimmeridgian and Early Kimmeridgian in age respectively based on an assessment of the 271 stratigraphical ranges of key taxa (Williams et al. 2013, fig. 5A). 


\section{Acknowledgements}

276 This paper was produced as part of a Research Council UK (RCUK) Individual Merit

277 research project entitled Global Jurassic dinoflagellate cyst palaeobiology and its

278 applications, and is published with the approval of the Executive Director, British Geological

279 Survey (NERC). The author is grateful to John E. Williams of the Department of

280 Palaeontology, The Natural History Museum, London, UK for advising on recent articles.

281 The input of two reviewers significantly improved this contribution.

JAMES B. RIDING is a palynologist with the British Geological Survey based in

Nottingham, United Kingdom. Jim is a specialist on Mesozoic-Cenozoic palynology, and works on a wide variety of domestic and international projects. One of his principal tasks is a RCUK Individual Merit research programme entitled Jurassic dinoflagellate cyst palaeobiology and its applications. This work aims to use the Jurassic dinoflagellate cyst record to effect long-scale correlations, to assess floral provincialism and to use dinoflagellate cysts to resolve palaeobiological questions. Jim is Secretary-Treasurer of the International Federation of Palynological Societies (IFPS).

\section{References}

Antonescu E, Avram E. 1980. Corrélation des dinoflagellés avec les zones d'ammonites et de calpionelles du Crétacé inférieur de Şviniţa - Banat. Annuaire de l'Institut de Géologie et de Géophysique 56:97-132.

Antonescu E, Baltreş A. 1998. Palynostratigraphie de la Formation de Nalbant (TriasJurassique) de la Dobrogea du Nord et des Formations Jurassiques du sous-sol du Delta de Danube (Plate-forme Scythienne). Geo-Eco-Marina 3:159-187. 
Beju D. 1971. Jurassic microplankton from the Carpathian Foreland of Roumania. Annales Instituti Geologici Publici Hungarici 54:276-317.

310 Birkenmajer K, Gedl P. 2012. Jurassic and Cretaceous strata in the Maruszyna IG-1 Deep 311 Borehole (Pieniny Klippen Belt, Carpathians, Poland): lithostratigraphy, dinoflagellate cyst

312 biostratigraphy, tectonics. Studia Geologica Polonica 135:7-54.

314 Borges MEN, Riding JB, Fernandes P, Pereira Z. 2011. The Jurassic (Pliensbachian to 315 Kimmeridgian) palynology of the Algarve Basin and the Carrapateira outlier, southern 316 Portugal. Review of Palaeobotany and Palynology 163:190-204.

318 Borges MEN, Riding JB, Fernandes P, Matos V, Pereira Z. 2012. Callovian (Middle Jurassic)

319 dinoflagellate cysts from the Algarve Basin, southern Portugal. Review of Palaeobotany and 320 Palynology 170:40-56.

Chen Y-Y. 2013. Palaecysta gen. nov., the greatest Systematophora imposter no more: introducing a lineage of latest Jurassic to Early Cretaceous (Tithonian-Hauterivian) dinoflagellate cysts from Madagascar. Palynology 37:259-297.

Dörhöfer G, Davies EH. 1980. Evolution of archeopyle and tabulation in Rhaetogonyaulacinean dinoflagellate cysts. Life Sciences Miscellaneous Publications of the Royal Ontario Museum, 91 p.

330 Evitt WR. 1985. Sporopollenin dinoflagellate cysts. Their morphology and interpretation. American Association of Stratigraphic Palynologists Foundation, Dallas, 333 p.

Feist-Burkhardt S. 1999. Sondierbohrung Benken: - Palynostratigraphie des Mittleren Jura.

334 (Teil A). Nationale Genossenschaft für die Lagerung Radioaktiver Abfälle, Interner Bericht, 335 Wettingen, Switzerland, $25 \mathrm{p}$.

Feist-Burkhardt S. 2012. Palynostratigraphie des Mittleren Jura: Teil I - Bohrungen Benken, 338 Schlattingen-1 und Weiach sowie einige Aufschlussproben der Lägern und deren Korrelation. Teil II - Bohrung Riniken, Aufschlussproben Bernhardholz, Dangstetten und Lägern. 
340 Nationale Genossenschaft für die Lagerung Radioaktiver Abfälle (Wettingen, Switzerland)

341 Arbeitsbericht, NAB 12-57, $71 \mathrm{p}$.

342

343 Fensome RA, Williams GL. 2004. The Lentin and Williams index of fossil dinoflagellates.

3442004 edition. American Association of Stratigraphic Palynologists Contributions Series No. $34542,909 \mathrm{p}$.

347 Fensome RA, Taylor FJR, Norris G, Sarjeant WAS, Wharton DI, Williams GL. 1993. A

348 classification of fossil and living dinoflagellates. Micropaleontology Press Special Paper 7, $349351 \mathrm{p}$.

Gedl P. 2013. Dinoflagellate cysts from the Szlachtowa Formation (Jurassic) and adjacent deposits (Jurassic-Cretaceous) of the Grajcarek Unit at Szczawnica-Zabaniszcze (Pieniny Klippen Belt, Carpathians, Poland). Geological Quarterly 57:485-502.

Habib D. 1975. Neocomian dinoflagellate zonation in the western North Atlantic.

Micropaleontology 21:373-392.

Habib D, Drugg WS. 1983. Dinoflagellate age of Middle Jurassic-Early Cretaceous sediments in the Blake-Bahama Basin. Initial Reports of the Deep Sea Drilling Project $36076: 623-638$.

Habib D, Drugg WS. 1987. Palynology of Sites 603 and 605, Leg 93, Deep Sea Drilling Project. Initial Reports of the Deep Sea Drilling Project 93:751-775.

Heilmann-Clausen C. 1987. Lower Cretaceous dinoflagellate biostratigraphy in the Danish Central Trough. Danmarks Geologiske Undersøgelse Serie A Nr. 17, 89 p.

368 Khowaja-Ateequzzaman, Garg R, Mehrotra NC. 2006. A catalogue of dinoflagellate cysts

369 from India. Diamond Jubilee Special Publication. Birbal Sahni Institute of Palaeobotany, 370 Lucknow, $167 \mathrm{p}$.

372 Kramers JW, Dolby G. 1993. Jurassic/Cretaceous boundary in west-central Alberta. Alberta 373 Research Council Open File Report 1993-26, 115 p. 
375 Li Jianguo, Peng Jungang, Batten DJ. 2013. Palynostratigraphy of a Jurassic-Cretaceous

Research 46:123-135.

MacRae RA, Fensome RA, Williams GL. 1996. Fossil dinoflagellate diversity, originations, and extinctions and their significance. Canadian Journal of Botany 74:1687-1694.

Mafi A, Ghasemi-Nejad E, Ashouri A, Vahidi-Nia M. 2013. Dinoflagellate cysts from the

Geosciences, doi:10.1007/s12517-013-0976-4.

Moldovanu M. 1984. Palynology of the Jurassic deposits in the sunken Northern area of the

Moesian Platform. University of Bucharest Laboratory of Palaeontology, 75 Years 19061981, Special Volume:55-66.

Monteil E. 1992a. Quelque nouvelles especes-index de kystes de dinoflagellés (Tithonique-

Valanginien) du sud-est de la France et de 1‘Ouest de la Suisse. Revue de Paléobiologie $11: 273-297$.

Monteil E. 1992b. Kystes de dinoflagellés index (Tithonique-Valanginien) du sud-est de la France. Proposition d'une nouvelle zonation palynologique. Revue de Paléobiologie 11:299_ 306.

Norris G. 1978. Phylogeny and a revised supra-generic classification for Triassic-Quaternary organic-walled dinoflagellate cysts (Pyrrhophyta). Part II. Families and sub-orders of fossil dinoflagellates. Neues Jahrbuch für Geologie und Paläontologie Abhandlungen 156:1-30.

403 Ogg G. 1994. Dinoflagellate cysts of the Early Cretaceous North Atlantic Ocean. Marine Micropaleontology 23:241-263. of genetic stratigraphic sequences in the Jurassic-lowermost Cretaceous (Hettangian to 
408 Ryazanian) of the North Sea and adjacent areas. In: Parker JR, editor. Petroleum Geology of

409 Northwest Europe: Proceedings of the 4th Conference. The Geological Society, London,

$410 \quad 371-386$ plus enclosures 1 and 2.

411

412 Poulsen NE, Riding JB. 2003. The Jurassic dinoflagellate cyst zonation of Subboreal

413 Northwest Europe. In: Ineson JR, Surlyk F, editors. The Jurassic of Denmark and Greenland.

414 Geological Survey of Denmark and Greenland Bulletin 1:115-144.

415

416 Riding JB. 2012. A compilation and review of the literature on Triassic, Jurassic, and earliest

417 Cretaceous dinoflagellate cysts. American Association of Stratigraphic Palynologists

418 Contributions Series No. 46, 119 p. plus CD ROM.

419

420 Riding JB. 2013. The literature on Triassic, Jurassic and earliest Cretaceous dinoflagellate cysts: supplement 1 . Palynology 37:345-354.

422

423 Riding JB, Thomas JE. 1992. Dinoflagellate cysts of the Jurassic System. In: Powell AJ, 424 editor. A stratigraphic index of dinoflagellate cysts. British Micropalaeontological Society 425 Publications Series. Chapman and Hall, London, 7-97.

Riding JB, Fensome RA. 2002. A review of Scriniodinium Klement 1957, Endoscrinium

428 (Klement 1960) Vozzhennikova 1967 and related dinoflagellate cyst taxa. Palynology 26:5429 33.

430

431 Riding JB, Michoux D. 2013. Further observations on the Jurassic dinoflagellate cyst 432 Gonyaulacysta dentata (Raynaud 1978) Lentin \& Vozzhennikova 1990 emended Riding 433 2012. Review of Palaeobotany and Palynology 196:51-56.

435 Sarjeant WAS, Downie C. 1966. The classification of dinoflagellate cysts above generic 436 level. Grana Palynologica 6:503-527.

438 Sarjeant WAS, Downie C. 1974. The classification of dinoflagellate cysts above generic 439 level: a discussion and revisions. Birbal Sahni Institute of Palaeobotany Special Publication $440 \quad 3: 9-32$. 
444 van de Schootbrugge B, Bachan A, Suan G, Richoz S, Payne JL. 2013. Microbes, mud and methane: cause and consequence of recurrent Early Jurassic anoxia following the endTriassic mass extinction. Palaeontology 56:685-709.

448 Williams SK, Krause FF, Knopp ST, Davies EH, Poulton TP, DeBuhr CL. 2013. The Niton

449 Member: A new Oxfordian to Kimmeridgian (Jurassic) glauconitic sandstone member, Fernie

450 Formation, west-central Alberta subsurface - sedimentology, biostratigraphy and regional considerations. Bulletin of Canadian Petroleum Geology 61:211-240.

\section{Appendix 1. List of Literature}

Contributions on Triassic to earliest Cretaceous dinoflagellate cysts issued after the publication of Riding (2012, 2013), and papers encountered after these compilations were made, are listed in alphabetical/chronological order below. The reference format used is much the same as in Riding (2013), which was slightly modified from Riding (2012). In the present contribution however, doi numbers are included where these are available. Fifteen papers which are deemed to be of major significance are asterisked. The language in which a paper was written in is indicated if it is not in English. A synthesis of the scope of each item is given as a string of keywords in parentheses after each citation. These keywords summarise the principal subject matter, age range, major geographical region(s) and country/countries. A distinction is made between publications which present new data ('primary data'), and those which compile, review or summarise existing data ('compilation'). Some abstracts are listed here; these are denoted by the word 'summary' in the keyword string. For the purposes of this work, the world is subdivided into 13 major geographical regions. These are Africa, Central America, North America, South America, Antarctica, the Arctic, Australasia, China, East Europe, West Europe, the Indian subcontinent, the Middle East and Russia (Table 1). 
AL-AMERI, T.K., and AL-MUSAWI, F.A. 2011. Hydrocarbon generation potential of the uppermost Jurassic-basal Cretaceous Sulaiy formation, South Iraq. Arabian Journal of Geosciences, 4: 53-58 (doi: 10.1007/s12517-009-0064-y). (organic geochemistry; palaeoecology; palynofacies; petroleum geology; primary data; Late Jurassic-Early Cretaceous [Tithonian-Valanginian]; Middle East [southern Iraq])

AL-AMERI, T.K., and AL-NAGSHBANDI, S.F. 2014. Age assessments and palynofacies of the Jurassic oil source rocks succession of North Iraq. Arabian Journal of Geosciences, doi: 10.1007/s12517-013-1245-2, 13 p. (online only). (biostratigraphy; palynofacies; petroleum geology; pollen and spores; primary data; Middle Jurassic-earliest Cretaceous [Bajocian-Berriasian]; Middle East [northern Iraq]) Hydrocarbons generation potential of the Jurassic-Lower Cretaceous Formation, Ajeel field, Iraq. Arabian Journal of Geosciences, 6: 3725-3735 (doi: 10.1007/s12517-012-0636-0). (biostratigraphy; organic geochemistry; palaeothermometry; palynofacies; petroleum geology; pollen and spores; primary data; Middle Jurassic-earliest Cretaceous [BathonianBerriasian]; Middle East [central Iraq])

ALAUG, A.S., MAHMOUD, M.S., DEAF, A.S., and AL-AMERI, T.K. 2013. Palynofacies, organic geochemical analyses and hydrocarbon potential of some Upper Jurassic-Lower

497 Cretaceous rocks, the Sabatayn-1 well, Central Yemen. Arabian Journal of Geosciences, doi: 10.1007/s12517-013-0961-y, 16 p. (online only). (organic geochemistry; palaeoecology; palynofacies; petroleum geology; pollen and spores;

500 primary data; Late Jurassic-Early Cretaceous [Oxfordian-Valanginian]; Middle East [central 501 Yemen])

*ANTONESCU, E., and AVRAM, E. 1980. Corrélation des dinoflagellés avec les zones d'ammonites et de calpionelles du Crétacé inférieur de Şviniţa - Banat. Annuaire de l'Institut de Géologie et de Géophysique, 56: 97-132 (in French with an English abstract).

506 (ammonites; biostratigraphy; calpionellids; correlation; primary data; Early Cretaceous

507 [Berriasian-Aptian]; East Europe [Romania]) 
*ANTONESCU, E., and BALTREŞ, A. 1998. Palynostratigraphie de la Formation de

510 Nalbant (Trias-Jurassique) de la Dobrogea du Nord et des Formations Jurassiques du sous-sol

511 du Delta de Danube (Plate-forme Scythienne). Geo-Eco-Marina, 3: 159-187 (in French with

512 an English abstract).

513 (biostratigraphy; lithostratigraphy; sedimentology; primary data; Late Triassic-Late Jurassic

514 [Norian-?Tithonian]; East Europe [Romania])

515

ALBERT, N.R., EVITT, W.R., and STEIN, J.A. 1984. Morphology of new Late Jurassic and

517 Early Cretaceous dinoflagellate cysts from California and Alaska. Palynology, 8: 233

518 (abstract).

519 (morphology; summary; Late Jurassic-Early Cretaceous [Oxfordian-Valanginian]; North

520 America [central-southern Alaska, California, USA])

521

522

*BACKHOUSE, J., and BALME, B.E. 2002. Late Triassic palynology of the northern

Carnarvon Basin. Minerals and Energy Research Institute of Western Australia (MERIWA) Report, No. 226, 181 p.

528 (biostratigraphy; lithostratigraphy; palaeoecology; palynofacies; palynozonation; petroleum geology; pollen and spores; systematics; primary data; Late Triassic-Early Jurassic [CarnianHettangian/Sinemurian]; Australasia [northern Carnarvon Basin, northwest Australia])

BARTOLINI, A., BONNOT, A., BOULILA, S., CHATEAU-SMITH, C., COLLIN, P.-Y., ENAY, R., FORTWENGLER, D., GALBRUN, B., GARDIN, S., HUAULT, V., HURET, E., JARDAT, R., MARCHAND, D., PELLENARD, P., RAYNAUD, D., and THIERRY, J. 2013. Integrated stratigraphy of some key Callovian-Oxfordian boundary sections in SouthEast France. Contribution to the choice of the Global Boundary Stratotype Section and point (GSSP) of the Oxfordian Stage. Fortwengler, D., Marchand, D., Pellenard, P., Thierry, J., and

538 Chateau-Smith, C. (eds.). Oxfordian GSSP Workshop $30^{\text {th }}$ September-2 ${ }^{\text {nd }}$ October 2013.

539 Field Guide 2013. Groupe Français d'Etude du Jurassique (GFEJ), 95 p.

540 (ammonites; biostratigraphy; calcareous nannofossils; chemostratigraphy;

541 chronostratigraphy; field guide; foraminifera; gamma-ray spectrometry; Global Boundary 
542 Stratotype Section and Point (GSSP); magnetic susceptibility; Milankovitch cyclicity; ostracods; Subalpine Basin; Terres Noires Formation; primary data; Middle-Late Jurassic

544 [Callovian-Oxfordian]; West Europe [southeast France])

*BIRKENMAJER, K., and GEDL, P. 2012. Jurassic and Cretaceous strata in the Maruszyna

IG-1 Deep Borehole (Pieniny Klippen Belt, Carpathians, Poland): lithostratigraphy, dinoflagellate cyst biostratigraphy, tectonics. Studia Geologica Polonica, 135: 7-54. (biostratigraphy; lithostratigraphy; palynofacies; structural geology; tectonics; primary data; Middle Jurassic-Late Cretaceous [Aalenian-Bathonian and Valanginian-Maastrichtian]; East Europe [Poland])

BRADSHAW, M., and CHALLINOR, A.B. 1992. 7. Australasia. In: Westermann, G.E.G. (ed.). The Jurassic of the Circum-Pacific. Cambridge University Press, Cambridge, UK, $162-$ 180.

(ammonites; belemnites; biostratigraphy; bivalves; brachiopods; lithostratigraphy; palaeoecology; palaeogeography; pollen and spores; regional geology; compilation; Late Triassic-earliest Cretaceous [Rhaetian-Berriasian]; Australasia [Australia, New Zealand])

BRENNER, W., and FOSTER, C.B. 1994. Chlorophycean algae from the Triassic of Australia. Review of Palaeobotany and Palynology, 80(3-4): 209-234 (doi: 10.1016/00346667(94)90002-7).

563 (Chlorophycean [green] algae; palaeoecology; review; systematics; taxonomy; primary data;

BURGER, D. 1995. Timescales: 9. Cretaceous. Australian Phanerozoic timescales. Survey Organisation) Record, 1995/38, 36 p. (ammonites; biostratigraphy; calcareous nannofossils; chronostratigraphy; eustasy; foraminifera; geomagnetism; holistic stratigraphy; plants; pollen and spores; vertebrates; compilation; latest Jurassic-latest Cretaceous [Tithonian-Maastrichtian]; Australasia [Australia]; worldwide) 
DEHBOZORGI, A., SAJJADI, F., and HASHEMI, H. 2013. Middle Jurassic palynomorphs 4697-z).

581 (biostratigraphy; palaeoecology; pollen and spores; primary data; Middle Jurassic [Bajocian-

582 Callovian]; Middle East [northeast Iran])

583

DETTMANN, M.E., MOLNAR, R.E., DOUGLAS, J.G., BURGER, D., FIELDING, C., CLIFFORD, H.T., FRANCIS, J., JELL, P., RICH, T., WADE, M., RICH, P.V., PLEDGE, N., KEMP, A., and ROZEFELDS, A. 1992. Australian Cretaceous terrestrial faunas and floras: biostratigraphic and biogeographic implications. Cretaceous Research, 13: 207-262 (doi: 10.1016/0195-6671(92)90001-7). (biostratigraphy; correlation; insects; nonmarine sediments; palaeoclimatology; palaeoecology; palaeogeography; plants; pollen and spores; vertebrates; compilation; latest Jurassic-Early Cretaceous [Tithonian-Aptian]; Australasia [Australia])

DONOVAN, A.D., DJAKIC, A.W., IOANNIDES, N.S., GARFIELD, T.R., and JONES,

\section{C.R. 1993. Sequence stratigraphic control on Middle and Upper Jurassic reservoir} distribution within the UK Central North Sea. In: Parker, J.R. (ed.). Petroleum Geology of Northwest Europe: Proceedings of the 4th Conference. The Geological Society, London, UK, 251-269.

(biostratigraphy; lithostratigraphy; palaeogeography; petroleum geology; sequence stratigraphy; compilation; Late Triassic-Early Cretaceous [Norian-Hauterivian]; West Europe [Central North Sea])

601

602

EATON, G.L. 1980. Nomenclature and homology in peridinialean dinoflagellate plate patterns. Palaeontology, 23(3): 667-688.

607 (homologous plates; Kofoidian tabulation system; tabulation; compilation; Late Triassic608 Jurassic-Holocene [undifferentiated]; no specific geographical focus) 
610 EDWARDS, L.E. 1993. 7. Dinoflagellates. In: Lipps, J.H. (ed.). Fossil Prokaryotes and

611 Protists. Blackwell Scientific Publications, Boston, USA, 105-127.

612 (biostratigraphy; biology/palaeobiology; classification; ecology; evolution; history;

613 morphology; review article; textbook; compilation; Late Triassic [undifferentiated]-

614 Holocene; no specific geographical focus)

615

616 EDWARDS, D., BALDAUF, J.G., BOWN, P.R., DORNING, K.J., FEIST, M.,

617 GALLAGHER, L.T., GRAMBAST-FESSARD, N., HART, M.B., POWELL, A.J., and

618 RIDING, R. 1993. 3. 'Algae'. In: Benton, M.J. (ed.). The Fossil Record 2. Chapman and

619 Hall, London, UK, 15-40.

620 (Acritarcha; Bacillariophyta; biostratigraphy; Charophyta; Chlorophyta; classification;

621 Euglenophyta; Haptophyta; incertae sedis; Prasinophyta; protists; Rhodophtyta; systematics;

622 compilation; Early Triassic-Quaternary [Induan-Holocene]; no specific geographical focus)

623

624 EVITT, W.R., and PIERCE, S.T. 1975. Early Tertiary ages from the coastal belt of the

625 Franciscan Complex, northern California. Geology, 3(8): 433-436 (doi: 10.1130/0091-

$6267613(1975) 3<433$ :ETAFTC $>2.0 . C O ; 2)$.

627 (biostratigraphy; Franciscan Complex; pollen; regional geology; reworking; primary data;

628 Late Jurassic [Oxfordian-Kimmeridgian], Cretaceous [undifferentiated-Albian-

629 Maastrichtian] and Paleogene [undifferentiated]; North America [California, U.S.A.])

630

631

632

$\mathbf{F}$

633

634 *FEIST-BURKHARDT, S. 1999. Sondierbohrung Benken: - Palynostratigraphie des

635 Mittleren Jura. (Teil A). Nationale Genossenschaft für die Lagerung Radioaktiver Abfälle

636 (NAGRA, Wettingen, Switzerland) Interner Bericht (unpublished), 25 p. (in German).

637 (biostratigraphy; miscellaneous aquatic palynomorphs; pollen and spores; reworking; primary

638 data; Early-Middle Jurassic [Toarcian-Bathonian]; West Europe [Switzerland])

639

640 *FEIST-BURKHARDT, S. 2012. Palynostratigraphie des Mittleren Jura: Teil I - Bohrungen

641 Benken, Schlattingen-1 und Weiach sowie einige Aufschlussproben der Lägern und deren

642 Korrelation. Teil II - Bohrung Riniken, Aufschlussproben Bernhardholz, Dangstetten und 
645 (biostratigraphy; boreholes; correlation; miscellaneous aquatic palynomorphs; pollen and 646 spores; reworking; primary data; Early-Late Jurassic [Toarcian-Oxfordian]; West Europe

647 [Germany, Switzerland])

648

649 FELESTTEEN, A.W., EL-SOUGHIER, M.I., MOHAMED, M.S., and MONGED, M.N.S.

650 2013. Hydrocarbon source potential of the Jurassic sediments of Salam-3X borehole, Khalda

651 Concession, Northern Western Desert, Egypt. Arabian Journal of Geosciences, doi:

$65210.1007 /$ s12517-013-0997-z, 14 p. (online only).

653 (organic geochemistry; palaeoecology; palaeothermometry; palynofacies; petroleum geology;

654 pollen and spores; primary data; Early-Late Jurassic [undifferentiated-Tithonian]; North

655 Africa [Western Desert, Egypt])

656

657

*FENSOME, R.A., TAYLOR, F.J.R., NORRIS, G., SARJEANT, W.A.S., WHARTON, D.I., and WILLIAMS, G.L. 1993. A classification of fossil and living dinoflagellates.

659 Micropaleontology Press Special Paper, No. 7, 351 p.

660 (evolution; historical review; integrated suprageneric classification; morphology; phylogeny; 661 taxonomy; compilation; Late Triassic-Holocene [undifferentiated]; no specific geographical 662 focus)

663

664 FENSOME, R.A., MacRAE, R.A., MOLDOWAN, J.M., TAYLOR, F.J.R., and WILLIAMS, 665 G.L. 1996. The early Mesozoic radiation of dinoflagellates. Paleobiology, 22(3): 329-338.

666 (biogeochemistry; biostratigraphy; diversity; evolution; morphology; phylogeny; radiation;

667 compilation; Late Triassic-Pliocene [Carnian-undifferentiated]; no specific geographical 668 focus)

669

670 FENSOME, R.A., SALDARRIAGA, J.F., and TAYLOR, F.R.J. "MAX”. 1999.

671 Dinoflagellate phylogeny revisited: reconciling morphological and molecular based

672 phylogenies. Grana, 38(2-3): 66-80. doi: 10.1080/00173139908559216.

673 (acritarchs; biogeochemistry; biostratigraphy; evolution; life cycles; molecular phylogenetics;

674 phylogeny; ultrastructure; morphology; compilation; Late Triassic-Pliocene [Carnian-

675 undifferentiated]; no specific geographical focus)

676 
677 FISK, L.H., KUMAR, A., RIDING, J.B., and RÖPER, M. 2013. Observations and

678 preliminary interpretations regarding the age and depositional environment of the Late

679 Jurassic Solnhofen Formation - evidence from palynomorphs. In: Clark, M., Lucas-Clark, J.,

680 and Fisk, L.H. (eds.). AASP - The Palynological Society $46^{\text {th }}$ Annual Meeting, San Francisco,

681 California, USA, October $20^{\text {th }}-24^{\text {th }}$ 2013, Abstracts and Program, 84-85.

682 (acritarchs; biostratigraphy; fossil lagerstätten; palaeoclimate; palaeoecology; pollen and

683 spores; summary; Late Jurassic [undifferentiated]; West Europe [Germany])

684

685

FRAKES, L.A., BURGER, D., APTHORPE, M., WISEMAN, J., DETTMANN, M.,

ALLEY, N., FLINT, R., GRAVESTOCK, D., LUDBROOK, N., BACKHOUSE, J.,

SKWARKO, S., SCHEIBNEROVA, V., McMINN, A., MOORE, P.S., BOLTON, B.R.,

DOUGLAS, J.G., CHRIST, R., WADE, M., MOLNAR, R.E., McGOWRAN, B., BALME,

689 B.E., and DAY, R.A. (AUSTRALIAN CRETACEOUS PALAEOENVIRONMENTS

690 GROUP). 1987. Australian Cretaceous shorelines, stage by stage. Palaeogeography,

691 Palaeoclimatology, Palaeoecology, 59: 31-48 (doi: 10.1016/0031-0182).

692 (biostratigraphy; palaeogeography; sea levels; shorelines; tectonics; compilation; latest

693 Jurassic-latest Cretaceous [Tithonian-Maastrichtian]; Australasia [Australia])

694

695

696

G

697

698 GARLAND, C.R. 1993. Miller Field: reservoir stratigraphy and its impact on development.

699 In: Parker, J.R. (ed.). Petroleum Geology of Northwest Europe: Proceedings of the 4th

700 Conference. The Geological Society, London, UK, 401-414.

701 (biostratigraphy; petroleum geology; sedimentology; compilation; Late Jurassic

702 [Kimmmeridgian-Tithonian]; West Europe [Northern North Sea])

*GEDL, P. 2013. Dinoflagellate cysts from the Szlachtowa Formation (Jurassic) and adjacent deposits (Jurassic-Cretaceous) of the Grajcarek Unit at Szczawnica-Zabaniszcze (Pieniny

Klippen Belt, Carpathians, Poland). Geological Quarterly, 57(3): 485-502 (doi: 10.7306/gq.1106).

708 (biostratigraphy; lithostratigraphy; primary data; Middle Jurassic and Early Cretaceous

709 [Aalenian-Callovian and Barremian-Albian]; East Europe [southern Poland]) 
711 GLASMANN, J.R., and WILKINSON, G.C. 1993. Clay mineral stratigraphy of Mesozoic and Paleozoic red beds, Northern North Sea. In: Parker, J.R. (ed.). Petroleum Geology of

713 Northwest Europe: Proceedings of the 4th Conference. The Geological Society, London, UK, $714625-636$.

715 (biostratigraphy; clay minerals; geochemistry; geothermometry; petroleum geology;

716 compilation; Late Triassic [Norian-Rhaetian]; West Europe [Northern North Sea])

718 GUERSTEIN, G.R., FENSOME, R.A., and WILLIAMS, G.L. 1998. A new areoligeracean dinoflagellate from the Miocene of offshore eastern Canada and its evolutionary implications. Palaeontology, 41(1): 23-34.

(biostratigraphy; phylogeny; taxonomy; compilation and primary data; Middle JurassicMiocene [Bathonian-Messinian]; North America [offshore East Canada])

HARRISON, J.C., WALL, J.H., BRENT, T.A., POULTON, T.P., and DAVIES, E.H. 1999.

Rift-related structures in Jurassic and Lower Cretaceous strata near the Canadian polar margin, Yukon Territory, Northwest Territories and Nunavut. Geological Survey of Canada Current Research 1999-E, 47-58. (ammonites; biostratigraphy; bivalves; correlation; foraminifera; regional geology; seismic stratigraphy; structural geology; tectonics; compilation; earliest Jurassic-Early Cretaceous [Hettangian-Aptian]; Arctic [Arctic Canada])

HSSAIDA, T., BENZAGGAGH, M., and RIDING, J.B. 2013. New biostratigraphic data on the dinoflagellate cysts of the Upper Jurassic Series from the External Rif Belt (Internal Prerif and Mesorif zones, Morocco). In: Clark, M., Lucas-Clark, J., and Fisk, L.H. (eds.). AASP The Palynological Society $46^{\text {th }}$ Annual Meeting, San Francisco, California, USA, October $20^{\text {th }}-24^{\text {th }}$ 2013, Abstracts and Program, 108.

740 (biostratigraphy; summary; Late Jurassic [Oxfordian-Tithonian]; North Africa [Morocco]) 
IVANOVA, D., LAKOVA, I., PAVLISHINA, P., and KOLEVA-REKALOVA, E. 2002.

Joint biostratigraphy and lithofacies of Berriasian and Valanginian limestones from subsurface sections in NE Bulgaria. Geologica Balcanica, 32(2-4): 63-67.

(biostratigraphy; calcareous microfossils; lithofacies; lithostratigraphy; primary data; Late Jurassic-Early Cretaceous [Tithonianian-Valanginian]; East Europe [northeast Bulgaria])

K

KENT, D.V., and GRADSTEIN, F.M. 1985. A Cretaceous and Jurassic geochronology. Geological Society of America Bulletin, 96(11): 1419-1427 (doi: 10.1130/00167606(1985)96<1419:ACAJG>2.0.CO;2).

(biostratigraphy; geochronology; magnetostratigraphy; compilation; Early Jurassic-Late Cretaceous [Pliensbachian-Cenomanian]; no specific geographical focus)

*KHOWAJA-ATEEQUZZAMAN, GARG, R., and MEHROTRA, N.C. 2006. A catalogue of dinoflagellate cysts from India. Diamond Jubilee Special Publication. Birbal Sahni Institute of Palaeobotany, Lucknow, 167 p.

(bibliography; biostratigraphy; catalogue; lithostratigraphy; compilation; Late TriassicQuaternary [undifferentiated]; the Indian subcontinent [India])

*KRAMERS, J.W., and DOLBY, G. 1993. Jurassic/Cretaceous boundary in west-central Alberta. Alberta Research Council (ARC) Open File Report, 1993-26, 115 p.

(biostratigraphy; correlation; lithostratigraphy; palaeogeography; regional geology; primary data; Early Jurassic-Early Cretaceous [Pliensbachian-Aptian]; North America [west-central Alberta, West Canada])

LEEREVELD, H., and WILPSHAAR, M. 1995. Boreal-Tethyan correlation of the Lower Cretaceous by means of dinoflagellate cysts. Stuifmail, 8(1): 13-23.

(biostratigraphy; compilation; summary; Early Cretaceous [Berriasian-Albian]; no specific geographical focus; pan-Northern Hemisphere [Boreal and Tethyan realms]) 
LEEREVELD, H., MAHMOUD, M.S., and LELOUX, J. 1990. Stratigraphic evaluation of

781 Early Cretaceous sporomorph assemblages from Egypt and Tunisia. Stuifmail, 13(3): 1-2.

782 (biostratigraphy; palynofacies; pollen and spores; primary data; Late Jurassic-Early

783 Cretaceous [Kimmeridgian-Berriasian and Hauterivian-Albian]; North Africa [Egypt,

784 Tunisia])

785

LELONO, E.B., and NUGRAHANINGSIH. 2012. Australian palinomorphs (sic.) from the

Buya Formation of the Sula Island. Scientific Contributions Oil \& Gas (Jakarta), 35(3): 115127.

789

(biostratigraphy; lithostratigraphy; palaeooceanography; petroleum geology; pollen and spores; primary data; Middle-Late Jurassic [Bathonian-Tithonian]; Australasia [Sula Islands, North Maluku, Indonesia])

LELOUX, J. 1991. Dinoflagellates of the Sidi Khalif Formation at the Jb. Meloussi, central Tunisia. Stuifmail, 9(1): 22-28.

(biostratigraphy; palaeoecology; palynofacies; reworking; primary data; Late Jurassic-Early

Cretaceous [Tithonian-Berriasian]; North Africa [Tunisia])

*LI JIANGUO, PENG JUNGANG, and BATTEN, D.J. 2013. Palynostratigraphy of a Jurassic-Cretaceous transitional succession in the Himalayan Tethys, southern Xizang (Tibet), China. Cretaceous Research, 46: 123-135 (doi: 10.1016/j.cretres.2013.08.012). (biostratigraphy; correlation; palaeogeography; pollen and spores; primary data; latest Jurassic-earliest Cretaceous [Tithonian-Berriasian]; China [Tibet, southwest China])

LINDSTRÖM, S., VOSGERAU, H., PIASECKI, S., NIELSEN, L.H., DYBKJÆR, K., and ERLSTRÖM, M. 2009. Ladinian palynofloras in the Norwegian-Danish Basin: a regional marker reflecting a climate change. Geological Survey of Denmark and Greenland Bulletin, 17: $21-24$.

808 (biostratigraphy; palaeoclimate; palaeoecology; pollen and spores; compilation; Middle

809 Triassic-Late Jurassic [Ladinian-Tithonian]; West Europe [Denmark, Norway])

811 LOSERT, J. 1986. Jurassic Rock Creek Member in the subsurface of the Edson area (west812 central Alberta). Alberta Research Council (ARC) Open File Report, 1986-3, 43 p. 
813 (biostratigraphy; correlation; lithostratigraphy; palaeoecology; regional geology; well logs;

814 primary data; Late Jurassic-Early Cretaceous [Oxfordian-Albian]; North America [west-

815 central Alberta, West Canada])

816

817 LOSERT, J. 1990. The Jurassic-Cretaceous boundary units and associated hydrocarbon pools

818 in the Niton Field, west-central Alberta. Alberta Research Council (ARC) Open File Report, 819 1990-1, 41 p.

820 (biostratigraphy; bivalves; correlation; foraminifera; lithostratigraphy; palaeoecology;

821 petroleum geology; regional geology; well logs; primary data; Middle Jurassic-Early

822 Cretaceous [Bajocian-Aptian]; North America [west-central Alberta, West Canada])

823

824 LUTERBACHER, H. 1994. 4.2. Remarks on the subdivision of the Upper Jurassic of 825 southern Germany by dinoflagellates. In: LEINFELDER, R.R. (editor and coordinator),

826 KRAUTTER, M., LATERNSER, K., NOSE, M., SCHMID, D.U., SCHWEIGERT, G.,

827 WERNER, W., KEUPP, H., BRUGGER, H., HERRMANN, R., REHFELD-KIEFER, U.,

828 SCHROEDER, J.H., REINHOLD, C., KOCH, R., ZEISS, A., SCHWEIZER, V.,

829 CHRISTMANN, H., MENGES, G., and LUTERBACHER, H. 1994. The origin of Jurassic

830 reefs: current research developments and results. Facies, 31: 28-31.

831 (ammonites; biostratigraphy; compilation; Late Jurassic [Oxfordian-Kimmeridgian]; West

832 Europe [Germany])

833

834

835

$\mathbf{M}$

836

837 MacRAE, R.A., FENSOME, R.A., and WILLIAMS, G.L. 1996. Fossil dinoflagellate

838 diversity, originations, and extinctions and their significance. Canadian Journal of Botany,

839 74(11): 1687-1694 (doi: 10.1139/b96-205).

840 (biotic turnover; database; diversity; evolution; palaeoecology; phylogeny; plankton; sea

841 levels; compilation; Middle Triassic-Quaternary [Anisian-undifferentiated]; no specific

842 geographical focus)

843

844 *MAFI, A., GHASEMI-NEJAD, E., ASHOURI, A., and VAHIDI-NIA, M. 2013.

845 Dinoflagellate cysts from the Upper Bajocian-Lower Oxfordian of the Dalichai Formation in 
846 Binalud Mountains (NE Iran): their biostratigraphical and biogeographical significance.

847 Arabian Journal of Geosciences, doi: 10.1007/s12517-013-0976-4, 10 p. (online only).

848 (biostratigraphy; palaeogeography; primary data; Middle-Late Jurassic [Bajocian-

849 Oxfordian]; Middle East [northeast Iran])

850

851 MAFI, A., GHASEMI-NEJAD, E., ASHOURI, A., and VAHIDI-NIA, M. 2014. A note on

852 the discovery of the suturocavate dinoflagellate cyst (Limbodinium absidatum) in the Middle

853 East (Binalud Mountains, NE Iran). Journal of African Earth Sciences, 92: 21-24 (doi:

854 10.1016/j.jafrearsci.2013.12.012).

855 (biostratigraphy; lithostratigraphy; palaeogeography; primary data; Middle-Late Jurassic

856 [Callovian-Oxfordian]; Middle East [northeast Iran])

857

858 McLAUGHLIN, R.J., SLITER, W.V., FREDERIKSEN, N.O., HARBERT, W.P., and 859 McCULLOCH, D.S. 1994. Plate motions recorded in tectonostratigraphic terranes of the

860 Franciscan Complex and evolution of the Mendocino Triple Junction, northwestern

861 California. U.S. Geological Survey Bulletin, No. 1997, 60 p.

862 (biostratigraphy; Franciscan Complex; pollen and spores; regional geology; reworking;

863 tectonics; terranes; primary data; Late Jurassic [Oxfordian-Kimmeridgian], Late Cretaceous

864 [undifferentiated] and Paleogene [Paleocene-Eocene]; North America [northern California, 865 USA])

866

867 *MOLDOVANU, M. 1984. Palynology of the Jurassic deposits in the sunken Northern area 868 of the Moesian Platform. University of Bucharest Laboratory of Palaeontology, 75 Years 869 1906-1981, Special Volume: 55-66.

870 (biostratigraphy; biozonation; correlation; primary data; Early-Late Jurassic [Toarcian-

871 Tithonian]; East Europe [Romania])

872

873 MONTRESOR, M., PROCACCINI, G., and STOECKER, D.K. 1999. Polarella glacialis, 874 gen. nov., sp. nov. (Dinophyceae): Suessiaceae are still alive! Journal of Phycology, 35(1): 875 186-197 (doi: 10.1046/j.1529-8817.1999.3510186.x).

876 (evolution; molecular phylogenetics; morphology; phylogeny; sea ice; taxonomy;

877 compilation and primary data; Late Triassic-Early Jurassic-Quaternary [undifferentiated-

878 Holocene]; Antarctica, no specific geographical focus)

879 

models; an updated dinoflagellate cyst, spore and pollen standard from the Late Jurassic-

883 Early Cretaceous of The Netherlands. In: Clark, M., Lucas-Clark, J., and Fisk, L.H. (eds.). 884 AASP - The Palynological Society $46^{\text {th }}$ Annual Meeting, San Francisco, California, USA, 885 October $20^{\text {th }}-24^{\text {th }}$ 2013, Abstracts and Program, 143.

886 (biostratigraphy; pollen and spores; summary; Middle Jurassic-Early Cretaceous [Callovian887 Berriasian]; West Europe [The Netherlands])

892 NICOLL, R.S. 2002. Conodont biostratigraphy and palaeogeography of the Triassic on the 893 western, northwestern and northern margins of the Australian Plate. In: Keep, M., and Moss, 894 S.S. (eds.). The sedimentary basins of Western Australia 3. Proceedings of the Petroleum 895 Exploration Society of Australia Symposium, Perth, Western Australia, 167-179.

896 (biostratigraphy; chronostratigraphy; conodonts; palaeogeography; pollen and spores;

897 tectonics; compilation; Middle-Late Triassic [Anisian-Rhaetian]; Australasia [Burma, 898 Indonesia, Papua New Guinea, Timor, Northern Territory, Western Australia], China 899 [southwest China])

900

901 NICOLL, R.S., and FOSTER, C.B. 1998. Revised biostratigraphic (conodont-palynomorph) zonation of the Triassic of Western and northwestern Australia and Timor. In: Purcell, P.G., and Purcell, R.R. (eds.). The sedimentary basins of Western Australia 2. Proceedings of the Petroleum Exploration Society of Australia, Perth, Western Australia, 129-139. (biostratigraphy; chronostratigraphy; conodonts; correlation; pollen and spores; compilation; Middle-Late Triassic [Anisian-Rhaetian]; Australasia [Timor, Western Australia])

*NORRIS, G. 1978. Phylogeny and a revised supra-generic classification for Triassic-

909 Quaternary organic-walled dinoflagellate cysts (Pyrrhophyta). Part II. Families and sub-

910 orders of fossil dinoflagellates. Neues Jahrbuch für Geologie und Paläontologie,

911 Abhandlungen, 156(1): 1-30.

912 (biostratigraphy; evolution; morphology; phylogeny; suprageneric classification; taxonomy;

913 compilation; Late Triassic-Pliocene [undifferentiated]; no specific geographical focus) 
917

918 PATERSON, N.W., MANGERUD, G., ASK, M., MØRK, A., and BJÆRKE, T. 2013.

919 Palynology of the Upper Triassic succession on Hopen, Arctic Norway. In: Clark, M., Lucas-

920 Clark, J., and Fisk, L.H. (eds.). AASP - The Palynological Society $46^{\text {th }}$ Annual Meeting, San

921 Francisco, California, USA, October $20^{\text {th }}-24^{\text {th }}$ 2013, Abstracts and Program, 155.

922 (biostratigraphy; palynofacies; pollen and spores; summary; Late Triassic [Carnian-Norian];

923 Arctic [Hopen Island, Svalbard region])

924

925

PIEŃKOWSKI, G. 2004. The epicontinental Lower Jurassic of Poland. Polish Geological

926 Institute Special Papers, 12, $152 \mathrm{p}$.

927 (biostratigraphy; correlation; eustasy; lithostratigraphy; sedimentology; sequence

928 stratigraphy; compilation; Early Jurassic [Hettangian-Toarcian]; East Europe [Poland])

929

930

POULTON, T.P., DETTERMAN, R.L., HALL, R.L., JONES, D.L., PETERSON, J.A.,

SMITH, P., TAYLOR, D.G., TIPPER, H.W., and WESTERMANN, G.E.G. 1992. 4. Western

932 Canada and United States, In: Westermann, G.E.G. (ed.). The Jurassic of the Circum-Pacific.

933 Cambridge University Press, Cambridge, UK, 29-92.

934 (ammonites; biostratigraphy; bivalves; lithostratigraphy; regional geology; compilation;

935 Middle-Late Jurassic [Bajocian-Tithonian]; Arctic [Arctic Canada])

936

937

938

\section{Q}

939

940 QUATTROCCHIO, M.E., MARTÍNEZ, M.A., CARPINELLI PAVISICH, A., and

941 VOLKHEIMER, W. 2006. Early Cretaceous palynostratigraphy, palynofacies and

942 palaeoenvironments of well sections in northeastern Tierra del Fuego, Argentina. Cretaceous

943 Research, 27(4): 584-602 (doi: 10.1016/j.cretres.2005.11.012).

944 (biostratigraphy; palaeoecology; palynofacies; pollen and spores; tectonics; primary data and 945 compilation; Early-Late Cretaceous [Berriasian-Cenomanian]; South America [Tierra del

946 Fuego, southern Argentina]) 
QUATTROCCHIO, M.E., VOLKHEIMER, W., BORRROMEI, A.M., and MARTÍNEZ, M.

2011. Changes of the palynobiotas in the Mesozoic and Cenozoic of Patagonia: a review.

950 Biological Journal of the Linnean Society, 103(2): 380-396 (doi: 10.1111/j.1095-

951 8312.2011.01652.x).

952 (evolution; floral history; palaeoecology; palaeogeography; pollen and spores; plants;

953 compilation; Early-Late Jurassic [Pliensbachian-Tithonian]; South America [Patagonia, 954 southern Argentina])

955

956

957

$\mathbf{R}$

958

959

RATTEY, R.P., and HAYWARD, A.B. 1993. Sequence stratigraphy of a failed rift system: the Middle Jurassic to Early Cretaceous basin evolution of the Central and Northern North

961 Sea. In: Parker, J.R. (ed.). Petroleum Geology of Northwest Europe: Proceedings of the 4th

962 Conference. The Geological Society, London, UK, 215-249.

963 (biostratigraphy; lithostratigraphy; palaeogeography; petroleum geology; seismic

964 stratigraphy; sequence stratigraphy; structural geology; compilation; Middle Jurassic-Early

965 Cretaceous [Aalenian-Berriasian]; West Europe [Central and Northern North Sea])

966

967 RIDING, J.B. 2013. The palaeobiology of Triassic and Jurassic dinoflagellate cysts. In:

968 Clark, M., Lucas-Clark, J., and Fisk, L.H. (eds.). AASP - The Palynological Society $46^{\text {th }}$

969 Annual Meeting, San Francisco, California, USA, October $20^{\text {th }}-24^{\text {th }} 2013$, Abstracts and

970 Program, 170.

971 (evolution; mass extinction; oceanic anoxic event; palaeobiology; palaeoecology;

972 palaeothermometry; summary; Late Triassic-Late Jurassic [Ladinian-Oxfordian]; no specific

973 geographical focus)

974

975 RIDING, J.B., and DETTMANN, M.E. 2013. The first Australian palynologist: Isabel

976 Clifton Cookson (1893-1973) and her scientific work. Alcheringa, 38: 97-129 (doi:

977 10.1080/03115518.2013.828252).

978 (biography; biostratigraphy; botany; fungi; history; palaeobotany; pollen and spores;

979 compilation; Late Jurassic-Holocene [Oxfordian-Holocene]; South America [Chile], Arctic

980 [Arctic Canada, Svalbard], Australasia [Australia, Papua New Guinea], West Europe

981 [England]) 
983 RUHL, M., BONIS, N.R., REICHART, G.-J., SINNINGHE-DAMSTÉ, J.S., and

984 KÜRSCHNER, W.M. 2011. Atmospheric carbon injection linked to end-Triassic mass 985 extinction. Science, 333(6041): 430-434 (doi: 10.1126/science.1204255).

986 (climate change; mass extinction; methane injection; organic geochemistry; vegetation;

987 volcanism; compilation; primary data; Triassic [Rhaetian]; West Europe [Austria, England])

988

989 RUHL, M., DEENEN, M.H.L., ABELS, H.A., BONIS, N.R., KRIJGSMAN, W., and

990 KÜRSCHNER, W.M. 2010. Astronomical constraints on the duration of the early Jurassic

991 Hettangian stage and recovery rates following the end-Triassic mass extinction (St Audrie's

992 Bay/East Quantoxhead, UK). Earth and Planetary Science Letters, 295(1-2): 262-276 (doi:

993 doi:10.1016/j.eps1.2010.04.008).

994 (astrostratigraphy; cyclostratigraphy; mass extinction; organic geochemistry; volcanism;

995 primary data; Late Triassic [Rhaetian]; West Europe [England])

996

997

998

\section{S}

999

1000 SARJEANT, W.A.S. 1960. The mystery of the hystrichospheres. Journal of the University of 1001 Sheffield Geological Society, 3(6): 262-268.

1002 (classification; history; hystrichospheres; review article; compilation; Late Jurassic 1003 [Oxfordian]; West Europe [England])

1004

1005

SARJEANT, W.A.S. 1965. The Xanthidia. Endeavour, 24(91): 33-39.

1006 (acritarchs; morphology; review article; xanthidia; compilation; Late Triassic-Holocene

1007 [undifferentiated]; Australasia [Australia], West Europe [England, Switzerland])

1009 SARJEANT, W.A.S. 1967. The Xanthidia - the solving of a palaeontological problem. The 1010 Mercian Geologist, 2(3): 245-266.

1011 (acritarchs; biography; biostratigraphy; Christian Gottfried Ehrenberg (1795-1876);

1012 classification; history; hystrichospheres; prasinophytes; review article; xanthidia;

1013 compilation; Middle Jurassic-Holocene [undifferentiated]; Arctic [Spitzbergen], West

1014 Europe [England, France, Germany])

1015 
1016 SARJEANT, W.A.S. 1970. Xanthidia, palinospheres and 'hystrix'. A review of the study of

1017 fossil unicellular microplankton with organic cell walls. Microscopy, 31(9): 221-253.

1018 (acritarchs; biography; biostratigraphy; Christian Gottfried Ehrenberg (1795-1876);

1019 classification; history; hystrichospheres; morphology; palaeoecology; palinospheres;

1020 prasinophytes; review article; xanthidia; compilation; Precambrian-Holocene

1021 [undifferentiated]; North America (Canada), Arctic [Spitzbergen], West Europe [England,

1022 France, Germany, Norway, Spain], Russia [undifferentiated])

SMITH, K., and RITCHIE, J.D. 1993. Jurassic volcanic centres in the Central North Sea. In:

Parker, J.R. (ed.). Petroleum Geology of Northwest Europe: Proceedings of the 4th

1026 Conference. The Geological Society, London, UK, 519-531.

1027 (biostratigraphy; mantle plume; seismic reflection; volcanism; primary data; Early Jurassic

1028 [Sinemurian]; West Europe [Central North Sea])

1030 STANLEY, G.D. Jr. 2006. Photosymbiosis and the evolution of modern coral reefs. Science, 312 (5775): 857-858 (doi: 10.1126/science.1123701). (coral reefs; corals; evolution; extinctions; Family Suessiacea; photosymbiosis; review

1033 article; compilation; Triassic-Jurassic [undifferentiated]; no specific geographical focus)

STANLEY, G.D. Jr., and VAN DE SCHOOTBRUGGE, B. 2009. Chapter 2. The evolution of the coral-algal symbiosis. In: van Oppen, M.J.H., and Lough, J.M. (eds.). Coral Bleaching. Patterns, processes, causes and consequences. Ecological Studies 205, SpringerVerlag, Berlin, Heidelberg (Germany), 7-19. (biostratigraphy; coral bleaching; evolution; Family Suessiaceae; photosymbiosis; reefs;

1040 review article; scleractinian corals; compilation; Late Triassic-Early Jurasssic [Carnian-

1041 Toarcian]; Australasia [northwest Australia], North Africa [Libya], West Europe [Austria, 1042 Germany, Sweden])

STEFFEN, D. 1993. Influence des variations eustatiques sur la distribution de la matière organique dans les roches sedimentaires: exemple des dépôts berriasiens des Bassins

1046 Vocontien, Ultrahelvétique et du Yorkshire. Publications du Departement de Geologie et de 1047 Paléontologie, Université de Genève, No. 13, 117 p. 
1048 (biostratigraphy; eustasy; organic geochemistry; sequence stratigraphy; palynofacies; primary

1049 data; latest Jurassic-earliest Cretaceous [Tithonian-Berriasian]; West Europe [England,

1050 France, Switzerland])

1051

STEFFEN, D., and GORIN, G. 1993a. Palynofacies of the Upper Tithonian - Berriasian deep sea carbonates in the Vocontian Trough (SE France). Bulletin des Centres de Recherches

1054 Exploration-Production Elf-Aquitaine, 17(1): 235-247.

1055 (biostratigraphy; sequence stratigraphy; palaeoecology; palynofacies; primary data; latest Jurassic-earliest Cretaceous [Tithonian-Berriasian]; West Europe [France])

STEFFEN, D., and GORIN, G. 1993b. Chapter 5. Sedimentology of organic matter in Upper Tithonian-Berriasian deep-sea carbonates of southeast France: evidence of eustatic control. In: Katz, B., and Pratt, L. (eds.). Source rocks in a sequence stratigraphic framework. AAPG (American Association of Petroleum Geologists) Studies in Geology, 37: 49-65. (biostratigraphy; eustasy; sequence stratigraphy; palynofacies; petroleum geology; primary data; latest Jurassic-earliest Cretaceous [Tithonian-Berriasian]; West Europe [France])

1064

STUKINS, S., JOLLEY, D.W., McILROY, D., and HARTLEY, A.J. 2013. Middle Jurassic vegetation dynamics from allochthonous palynological assemblages: An example from a marginal marine depositional setting; Lajas Formation, Neuquén Basin, Argentina.

1068 Palaeogeography, Palaeoclimatology, Palaeoecology, 392: 117-127 (doi

1069 10.1016/j.palaeo.2013.09.002).

1070 (palaeoecology; pollen and spores; statistics; taphonomy; vegetation dynamics; primary data;

1071 Middle Jurassic [Bajocian]; South America [Argentina])

1073 STUKINS, S., McILROY, D., and RIDING, J.B. 2013. Comparative biostratigraphy and 1074 palaeoenvironment analysis between the upper and lower Lajas Formation, Neuquén Basin 1075 from Portada Covunco and Sierra de Chacaico. In: Clark, M., Lucas-Clark, J., and Fisk, L.H. 1076 (eds.). AASP - The Palynological Society 46 ${ }^{\text {th }}$ Annual Meeting, San Francisco, California, 1077 USA, October 20 ${ }^{\text {th }}-24^{\text {th }} 2013$, Abstracts and Program, 184.

1078 (biostratigraphy; palaeoecology; pollen and spores; summary; Middle Jurassic [Bajocian1079 Callovian]; South America [Argentina) 
SUKAMTO, R., and WESTERMANN, G.E.G. 1992. 8. Indonesia and Papua New Guinea. In: Westermann, G.E.G. (ed.). The Jurassic of the Circum-Pacific. Cambridge University Press, Cambridge, UK, 181-193.

1084 (ammonites; belemnites; biostratigraphy; bivalves; foraminifera; lithostratigraphy;

1085 palaeoecology; palaeogeography; radiolaria; regional geology; compilation; Middle Jurassicearliest Cretaceous [Callovian-Berriasian]; Australasia [Papua New Guinea])

TRAVERSE, A. 1988. Chapter 12. Late "Mesophytic" "non-pollen” palynomorphs. In:

Paleopalynology. Unwin Hyman, London, UK, 240-254.

1093 (acritarchs; biology; history; life cycle; megaspores; morphology; synthesis; textbook; compilation; Late Triassic-Jurassic [undifferentiated and Pliensbachian-Kimmeridgian]; Arctic [northern Alaska, East Greenland]; West Europe [England])

TRAVERSE, A. 1988. Chapter 13. Jurassic-Cretaceous palynology: end of the "Mesophytic." Advent and diversification of angiosperms. In: Paleopalynology. Unwin Hyman, London, UK, 255-288.

1100 (acritarchs; angiosperms; biostratigraphy; evolution; Cretaceous-Paleogene event; megaspores; normapolles pollen; pollen and spores; provincialism; compilation; Early-Late Cretaceous [undifferentiated-Cenomanian]; North America [northwest Alberta, Canada; Wyoming, USA])

TRAVERSE, A. 2008. Chapter 12. Triassic-Jurassic megaspores, dinoflagellates, other microplankton. In: Paleopalynology, second edition. Landman, N.H., and Jones, D.S. (eds.). Topics in Geobiology, 28: 325-345, Springer, Dordrecht, The Netherlands. (acritarchs; biology; history; life cycle; megaspores; morphology; synthesis; textbook; compilation; Late Triassic-Jurassic [undifferentiated and Pliensbachian-Kimmeridgian]; Arctic [northern Alaska, East Greenland]; West Europe [England])

1112 TRAVERSE, A. 2008. Chapter 13. Jurassic-Cretaceous palynology: end of the 1113 "Mesophytic." Advent and diversification of angiosperms. Dynamic evolution of 
1114 dinoflagellates. In: Paleopalynology, second edition. Landman, N.H., and Jones, D.S. (eds.).

1115 Topics in Geobiology, 28: 347-390, Springer, Dordrecht, The Netherlands.

1116 (acritarchs; angiosperms; biostratigraphy; Cretaceous-Paleogene event; evolution;

1117 megaspores; normapolles pollen; pollen and spores; provincialism; compilation; Middle

1118 Jurassic-Late Cretaceous [Callovian-Cenomanian]; Australasia [Australia, Indonesia, New

1119 Zealand], North America [northwest Alberta, Canada; Wyoming, USA])

WARRINGTON, G. 1987. The Late Triassic and Early Jurassic palynomorph succession in Somerset, England. Palynology, 11: 257 (abstract).

1126 (ammonites; biostratigraphy; lithostratigraphy; summary; Late Triassic-Early Jurassic

1127 [Carnian-Toarcian]; West Europe [England])

WIERZBOWSKI, A., and ROGOV, M.A. 2013. Biostratigraphy and ammonites of the Middle Oxfordian to lowermost Upper Kimmeridgian in northern Central Siberia. Russian Geology and Geophysics, 54: 1083-1102 (doi: 10.1016/j.rgg.2013.07.02).

1132 (ammonites; biostratigraphy; correlation; phylogeny; taxonomy; compilation and primary

1133 data; Late Jurassic [Oxfordian-Kimmeridgian]; Arctic [North Siberia, northern Russia])

WIGGINS, V.D. 1987. Upper Triassic (Late Carnian-Early Norian) dinocyst assemblages

1136 from northern Alaska. Palynology, 11: 258 (abstract).

1137 (biostratigraphy; summary; Late Triassic [Carnian-Rhaetian]; Arctic [northern Alaska])

*WILLIAMS, S.K., KRAUSE, F.F., KNOPP, S.T., DAVIES, E.H., POULTON, T.P., and

1140 DeBUHR, C.L. 2013. The Niton Member: A new Oxfordian to Kimmeridgian (Jurassic)

1141 glauconitic sandstone member, Fernie Formation, west-central Alberta subsurface -

1142 sedimentology, biostratigraphy and regional considerations. Bulletin of Canadian Petroleum

1143 Geology, 61(3): 211-240 (doi: 10.2113/gscpgbull.61.3.211).

1144 (biostratigraphy; lithostratigraphy; petroleum geology; petrology; regional geology; trace

1145 fossils; primary data; Late Jurassic [Oxfordian-Kimmmeridgian]; North America [west-

1146 central Alberta, West Canada]) 
ZAKHAROV, V.A., ROGOV, M.A., DZYUBA, O.S., ŽÁK, K., KOŠT’ÁK, M., PRUNER,

1152 P., SKUPIEN, P., CHADIMA, M., MAZUCH, M., and NIKITENKO, B.L. 2014.

1153 Palaeoenvironments and palaeoceanography changes across the Jurassic/Cretaceous

1154 boundary in the Arctic realm: case study of the Nordvik section (north Siberia, Russia). Polar

1155 Research, 33: 19714, http://dx.doi.org/10.3402/polar.v33.19714, 19 p. (online only).

1156 (ammonites; belemnites; biodiversity; biostratigraphy; bivalves; eustasy; foraminifera;

1157 Jurassic-Cretaceous boundary; palaeoceanography; palaeoclimatology; palaeoecology;

1158 prasinophytes; spores; stable isotope geochemistry; primary data; latest Jurassic-earliest

1159 Cretaceous [Tithonian-Berriasian]; Arctic [North Siberia, northern Russia])

\section{Appendix 2. List of dinoflagellate cyst species and subspecies}

1163

1164 This Appendix alphabetically lists all valid, formally-defined dinoflagellate cyst taxa below

1165 generic level which are mentioned in this contribution with full author citations. References

1166 to the author citations can be found in Fensome \& Williams (2004).

1168 Amphorula metaelliptica Dodekova 1969

1169 Belodinium dysculum Cookson \& Eisenack 1960

1170 Biorbifera johnewingii Habib 1972

1171 Carpathodinium predae (Beju 1971) Drugg 1978

1172 Chytroeisphaeridia chytroeides (Sarjeant 1962) Downie \& Sarjeant 1965

1173 Cribroperidinium crispum (Wetzel 1967) Fenton 1981

1174 Ctenidodinium combazii Dupin 1968

1175 Ctenidodinium continuum Gocht 1970

1176 Ctenidodinium ornatum (Eisenack 1935) Deflandre 1938

1177 Ctenidodinium tenellum Deflandre 1938

1178 Dapsilidinium warrenii (Habib 1976) Lentin \& Williams 1981

1179 Dichadogonyaulax sellwoodii Sarjeant 1975

1180 Dingodinium cerviculum Cookson \& Eisenack 1958 (formerly Dingodinium albertii Sarjeant $1181 \quad 1966)$ 
1182 Druggidium apicopaucicum Habib 1973

1183 Druggidium deflandrei (Millioud 1969) Habib 1973

1184 Endoscrinium asymmetricum Riding 1987

1185 Gochteodinia mutabilis (Riley in Fisher \& Riley) Fisher \& Riley 1982

1186 Hebecysta balmei (Stover \& Helby 1987) Below 1987

1187 Histiophora ornata Klement 1960

1188 Lanterna sportula Dodekova 1969

1189 Leptodinium subtile Klement 1960

1190 Meiourogonyaulax caytonensis (Sarjeant 1959) Sarjeant 1969 (formerly Lithodinia

1191 caytonensis (Sarjeant 1959) Gocht 1976)

1192 Meiourogonyaulax stoveri Millioud 1969

1193 Nannoceratopsis deflandrei Evitt 1961

1194 Nannoceratopsis deflandrei Evitt 1961 subsp. senex (van Helden 1977) Ilyina in Ilyina et al.

11951994 (formerly Nannoceratopsis senex van Helden 1977)

1196 Nannoceratopsis gracilis Alberti 1961

1197 Nannoceratopsis pellucida Deflandre 1938

1198 Nannoceratopsis spiculata Stover 1966

1199 Nannoceratopsis triceras Drugg 1978

1200 Oligosphaeridium? asterigerum (Gocht 1959) Davey \& Williams 1969

1201 Oligosphaeridium complex (White 1842) Davey \& Williams 1966

1202 Phoberocysta neocomica (Gocht 1957) Millioud 1969

1203 Prolixosphaeridium parvispinum (Deflandre 1937) Davey et al. 1969

1204 Rynchodiniopsis? regalis (Gocht 1970) Jan du Chêne et al. 1985 (formerly Leptodinium

1205 regale Gocht 1970$)$

1206 Scriniodinium crystallinum (Deflandre 1938) Klement 1960

1207 Scriniodinium? oxfordianum Sarjeant 1962

1208 Systematophora areolata Klement 1960

1211 Caption for Table 1:

1213 Table 1. A breakdown of the 89 publications on Triassic to earliest Cretaceous dinoflagellate

1214 cysts compiled herein, based on the geographical region(s) and the initial letter of the family 1215 name of the first author. 